\title{
LITERACY BASED SHARING KNOWLEDGE ON THE COMMUNITY
}

\author{
Andi Asari*, Dwi Saksomo, Amalia Nurma Dewi, Dwi Novita Ernaningsih \\ (State University of Malang, Semarang Jalan 5 Malang)
}

\begin{tabular}{|c|c|}
\hline A R T I C L E I N F O & A B S T R A C T \\
\hline $\begin{array}{l}\text { Keyword: } \\
\text { information literacy, } \\
\text { community, PERTUNI }\end{array}$ & $\begin{array}{l}\text { This study is a community-based information literacy studies on DPD PERTUNI } \\
\text { community Malang. The purpose of this study is to describe the role of communities } \\
\text { in developing information literacy PERTUNI members, describing the strategy and } \\
\text { the characteristics as contained in the Community Pertuni. The method used is a } \\
\text { qualitative method with a case study approach. Through case studies of the results of } \\
\text { this study indicate that information literacy using a social approach to take advantage } \\
\text { of community ties, a significant role in information literacy community members. } \\
\text { Recognized members of the community that they have a higher information literacy } \\
\text { while joining the community. }\end{array}$ \\
\hline
\end{tabular}

\section{INTRODUCTIONS}

During this approach to information, literacy tends emphasis on the ability and penchant for reading texts and use of information technology for search (Kay and Ahmadpour, 2015). But what about the people who have limited access to technology such as text and visually impaired? The answer is to develop new approaches to information literacy by using community. The approach through the community to see that in practice the information literacy is not a closed process limited to the interaction between information technology and human reason alone, but involves the community. Komunitaslah who produce the information. Information produced and then disseminated and access to such information is affected by social relations when the information is used, and interpreting the use and validation of information is affected by the social construction of the community. From the description, it is clear that information literacy and community are two things that are closely related and can not be separated (Hicks, A., \& Lloyd, A. 2016)

One community that development effort is a community-based information literacy Indonesian Blind Union (Pertuni). Efforts are being made among others by setting up a digital library branch in various areas such as Semarang and Yogyakarta (used as pilot areas) which are equipped with advanced technology to facilitate the special needs of the blind. But it turns out, the library set up by Pertuni have not been able to play a significant role in the development of information literacy. This happens because of their resistance to the technology and a lack of awareness about the importance of information PERTUNI members (the Goddess, 2015). Failure to follow up a digital library to develop information literacy,

Pertuni Community Regional Representatives Council ( DPD) Malang is one branch of the society fairly active role in the business development of literacy blind. Community Board to provide information needed by the blind who are members of the community, then the weekly meeting of the board to distribute such information through discussion and motivation are conducted through a personal approach that PERTUNI members would take advantage of the information provided in order to improve the quality of life. In addition, Community Pertuni Malang also active in cooperation with

\footnotetext{
${ }^{*}$ Corresponding author.

E-mail addresses: andi.asari.fs@um.ac.id (andi asari)
}

ISSN : 2597-7385 (Online) - ISLLAC : Journal of Intensive Studies on Language, Literature, Art, and Culture is licensed under Creative Commons Attribution-ShareAlike 4.0 International License (http://creativecommons.org/licenses/BY/4.0/). 
various other parties that information literacy PERTUNI members is not limited to information relating to blindness alone (http://mediacenter.malangkota.go.id,) But also to the surrounding environment.

Information literacy has an important role in increasing the participation of individuals to be able to play an active role in the information age. Information literacy has a variety of definitions that are affected by a wide range of viewpoints that are used to assess these. ALA (American Library Association), look through the information literacy behavioristic approach so that they define as the information literacy skills of individuals to be aware of the information needs, search, evaluate, and use effectively the acquired information (Ahmadpour, 2014).

According to the Indonesian Blind Union (Pertuni), the blind are people who still have some usable vision but were unable to use their vision to read an ordinary stylus 12 points in a state of normal light though aided by glasses (low vision) to those who can not see at all or totally blind (Pertuni, 2009). Another definition according to Mason, H. \& Mc Call describes the blindness of the educational side. According to them, two people have the same level of visual acuity does not necessarily indicate the usefulness of the same. Experience has shown that visual acuity is not enough to predict how a person uses the remaining vision to utilize information and develop themselves continuously (Mason, H. \& Mc Call, 1999).

In research conducted by Bradi, et al. In 2013 on the blind interaction with information is found that there are distinct characteristics of the interaction between the blind and information. In developed countries, where blind people familiar with the technology they are using the technology as the "eyes" to collect information about everything that can not be seen. One is the use of a variety of applications such as Social VisWiz or JAWS. These applications allow the blind to get information on what can not be seen/read it. For example asking for information about an image, color, statistical data, and others are converted into voice so that the blind can easily find and use information (Bradi, et al., 2013). As with the existing visual impairment in developing countries like Indonesia. Based on research conducted by Pertuni illiteracy among (braille letters) is still high and the majority of blind people are not familiar with the use of technology (Pertuni, 2009), on the other hand, the information management of government institutions such as libraries still lacking in attention to the special needs of the blind.

Lack of access to information, lack of attention to the needs of governments and communities special ones available for the community to encourage the visually impaired to form a community that could facilitate their specific needs in order to encourage the blind to be able to live a normal life in society. Based on the national conference conducted by community Pertuni disclosed that one of the resulting resolution is an attempt to minimize the discrimination of social still quite high in Indonesian society through the establishment of a community's rights visually impaired, provide support and motivation to move forward for the visually impaired as well as a resolution to increase access to information in order to develop literacy blind in Indonesia (Pertuni, 2009). Based on this background the development of community-based literacy needs to be done because it is considered more appropriate for the visually impaired. One community that implement community-based information literacy for the blind is Pertuni Community.

\section{METHOD}

Research on the development of community-based information literacy in the community Pertuni qualitative method with a case study approach. Qualitative methods have been selected for the purpose of this study was to gain insight into the practice of community-based information literacy, which the researchers focused on studying and interpret patterns of social interaction that is seen from the communication, information sharing, collaboration in the community.

This study uses a variety of data sources so that researchers can develop a detailed description of the practice of literacy. The target in this study is not a measurement of information literacy level, but understanding and deep analysis of social interaction in the community and how such interactions PERTUNI used to develop information literacy community members.

According to Yin, case studies are used to explain the decision, stages, process, or program, why they were taken, how they are implemented, and with what results (Yin, 2003), based on the statement of Yin are the reason this study using case studies is that researchers wanted to examine in depth and thorough information literacy practices developed by the Community Pertuni DPD Malang. 


\section{FINDINGS AND DISCUSSIONS}

Sharing information is a key to successful development of community- based information. Now with a variety of existing media to share information becomes much easier. Ease of sharing information about changing how information literacy interpreted. Information literacy is now rapidly shifting to production information collaboratively and share information in mass (Mackey and Jacobson, 2011).

According Ahmadpour sharing of information has a significant role in the development of community literacy. Information shared by community members rated stimulate literacy community members, rather than the information obtained from outside the community is so because of such information in accordance with the information needs and characteristics of the community, accessible, and relevant for use by most members of the community (Ahmadpour, 2014).

Share information among members of the community has a tendency done informally and related to the information about the experiences, needs and daily activities. Can be done through social media and group discussion. Share important information carried by a community so that their distribution of information and skills evenly use of information in the community (Ferguson, 2009). There are various models of sharing knowledge that can be used to observe the sharing of knowledge in the community, one of which is SECI.

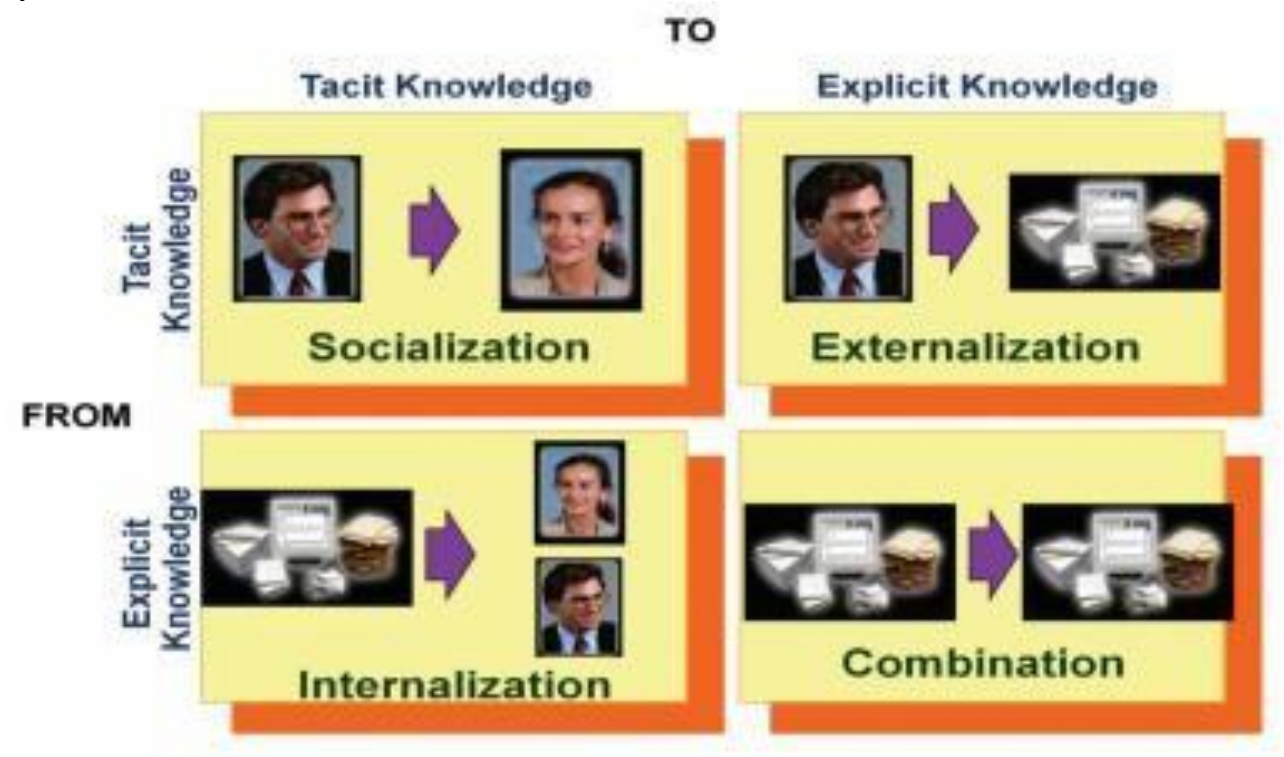

Picture knowledge conversion model (Adapted from SECI Process, Nonaka \& Takeuchi, 1995) by Paul Lumbantobing 2011.

Knowledge sharing process begins with socialization th a $\mathrm{t}$ involves members of the community to share information that is in their minds, in this process the individual has awareness of the importance of sharing of information, where they are aware of the information that they know will be owned jointly. After socialization, followed by externalization. Externalization herein refers to the various ways in which to express the information held by a person with the aim that others can understand it in this process, the individual merges with the community. Information that has been externalized subsequently combined, edited, processed, and disseminated throughout the community members who then will be followed by a process of internalization. Internalization is how the information has been combined before can be owned and used by all community members. Through information sharing, information literacy rooted, spread, gained in all aspects of the community, all members will develop together and there's nothing left (Nonaka and Konno, 2000).

Share information on community awareness Pertuni have a significant role in improving information literacy community members, but not all members of the community aware of the importance of sharing information. Some community members have a tendency to store information for personal gain, for example, there are some members who are a proficient technology open 
source software called JAWS. They are reluctant to share information related to these technologies to other members unless the other members of their pay.

Components of information literacy in social perspective is to share information. Sharing information is an activity that focuses on the delivery of information for all members of the community that aims to distribute information and skills evenly uses of information, which will then increase literacy information from members of the community so as to improve their quality of life.

\section{Socialization}

Socialization is the process of sharing and creation of tacit knowledge through interaction and direct experience. Tacit knowledge is delivered through a process of discussion based on the awareness that the information they have to be distributed to members of the community for the betterment of the community PERTUNI. The promotion phase, where awareness of the importance of sharing of information must be grown, but it does not always go well. Not all members of the community have the awareness and sense of responsibility are the same. Thus, sometimes the head of the community should anticipate by certain ways, such as giving social pressure or other means to the member. Although there are some members of the community who cannot play an active role in the promotion phase, it is not an obstacle for the majority of members have awareness of the importance of sharing information. They always have a way to encourage members of the stingy information to share information of mutual interest.

Nevertheless, the majority of community members understand the importance of sharing information. They are always able to anticipate members' stingy information "is. One member will pay the related information JAWS, then the members will share obtained information to other community members for free. Awareness of information sharing among community members based on the desire and sense of responsibility of members in promoting information literacy among the community of PERTUNI. They want community members to have extensive knowledge so it is not left behind by people who are not special needs.

\section{Externalization}

Externalization is the process of transforming tacit knowledge into explicit knowledge through a process of dialogue and reflection. In other words, share knowledge owned by an individual to others. The concept or idea shared by members of the organization distributed to members of the group. In doing externalization of their knowledge, they prefer to do through direct communication or demonstrate how, because not all community members are totally blind, but nothing has weak eyesight, so they can see.

Through externalization, community members can learn from each other. Hardships associated externalization is that they feel less able to convey what is well thought out, although against a fellow community member. Although in doing externalizing no barriers, but because the majority of members have the same interests they build a community, it gives birth to the Community of Interest, this community has been more in-depth discussion and had talked about certain topics that are still in the domain of common interests. More sophisticated community next Community of Practice, where this community had an exchange of knowledge and its application. For example, how to operate a specific application or how to sell a product to a specific client.

\section{Combination}

The combination of manipulating explicit knowledge held by individuals by means of sorting, add or combine among several explicit knowledge. This can occur for example through the process of sharing knowledge and field practice. After their meetings and discussions between members, through information received from other people can come up with new ideas more effectively and creatively to apply. Currently, Pertuni community members can take advantage of the acquired information to improve the quality of life, which in this case with regard to income, then these members can be judged as being literate. Not only related to the massage parlors, from results of the meeting and the discussion came the idea to hold a specialized information technology training for members Pertuni. 


\section{Internalization}

Internalization is a process of learning and knowledge acquisition carried out by members of the organization to the explicit knowledge that is disseminated throughout the organization through their own experience that it becomes tacit knowledge organization members. Through the process of internalization, explicit knowledge learned can be understood by community members (Lumbantobing, 2011).

The knowledge that has undergone a process of internalization, back into tacit knowledge, which then needs to be converted back into explicit knowledge, so forth. Through this cycle, from time to time Pertuni community knowledge assets will increasingly become rich in knowledge and grow in the era of information technology. Which raised awareness of the need to share information, know how to access information, understand how to evaluate the information, and be able to use information in accordance with the ethics and laws for the common interest and to achieve the goal of DPD Pertuni Malang.

The ability of community organizations to manage knowledge is mostly located in the minds and behavior of individuals in the form of tacit knowledge for explicit then internalize back is a challenge that must be answered. The challenge that is the one driving the need for the implementation of information sharing. Because one of the benefits of sharing information to keep the knowledge in order to be maintained and always available for study. So that knowledge can be maintained, it is necessary to do the conversion of tacit knowledge shared by members into explicit knowledge so that whenever a member of the owner of tacit knowledge leaves the organization, did not happen the loss of knowledge that can be detrimental to the organization/community Pertuni DPD Malang.

\section{CONCLUSIONS AND SUGGESTIONS}

Pertuni information literacy research community in a social perspective viewed information literacy is not just to provide information and provide expertise in information search strategy only, further study was able to see the basic things that are usually overlooked when designing information literacy, which is a psychological condition and social ties. Literacy is not only a problem being able to read or able to harness technology, but information literacy is a social practice that is influenced by various social conditions beyond the individual, which has particularly significant effect of being able to play a role in creating conditions of psychological and cognitive encourage a person to consistently and continually for increasing the level of information literacy. Through case studies, Pertuni community, see that information literacy using a social approach to utilize community bonds, a significant role in information literacy community members. Recognized members of the community that they have a higher information literacy while joining the community know that high for community members.

The characteristics and values that exist in Pertuni Community is the establishment of proximity between community members and the chairman and the person that is considered important in the community are persistent in motivating members to be able to develop information literacy. Several strategies are being made to develop information literacy DPD member Malang Pertuni do with socialization, externalization, combination, and internalization. The fourth stage is a strategy that is done continuously to improve information literacy community members until that information can be owned and used (internalization) by all community members Pertuni Malang.

Based on the above conclusions put forward suggestions regarding this study. First, Community Pertuni Malang DPD should be more open to receiving information from other communities and in collaboration with various types of communities outside the blind community so that they can get the information that is more extensive and diverse, not just struggling with a disability only. This is intended to minimize the gap between the information literacy development community is not blind to the blind people who are members of the community. Second, government agencies and other institutions that cooperate with DPD Malang Pertuni community should understand the commitment and role as a 'bridge' to assist communities to develop information literacy Pertuni, 


\section{REFERENCES}

Afandi, A S. (2014). "The Commission Malang Socialize 2014 presidential election to Pertuni". Downloaded of http://mediacenter.malangkota.go.id.age. DESIDOC Journal of Library \& Information Technology, 28 (2), 39-47.

Ahmadpour, K. (2014). "Developing a Framework for Understanding Information Literacy in the 21st Century". Downloaded of http://faculty.uoit.ca

Andriadi, F. (2016). Democracy in Hand Netizen. Jakarta: CRM BOOKS change. Hillsdale. Lawrence Erlbaum Associates. comprehension activity. In L. Resnick, J. Levine and S. Teasley (Eds.),

Creswel, J. W. (2014). Research design: qualitative, quantitative and mixed methods approach. 4thed. Los Angeles: SAGE.

Dewi, A. N. (2015). "Poverty in the Community Information X" in potpourri Integration Librarian Towards Information Society: a socio-cultural perspective (Ed. Ike Iswary Lawanda). Depok: Sagung Seto.

Doolittle \& MacDonald. (1978). Communication and Sense of Community in a Metropolitan Neighborbood: a factor analytical examination. Communication Quarterly, Vol.26.

Eisenberg, M. (2008). Information literacy: Essential skills for the information

Ferguson, M. (1986). New Communication Technologies and the Public Interest. Canada: Sage,

Ferguson, S. (2009). "Information literacy and its relationship to knowledge management". Journal of Information Literacy, $\quad 3 \quad$ (2), $\quad$ pp. 24.http://ojs.lboro.ac.uk/ojs/index.php/JIL/article/view/PRA-V3-I2-2009-1,

Godbey, S. (2013). Collaboration as an Essential Tool in Information Literacy Education 9-16: Context, Qualities, and implications. SLIS Journal

Harris, B.R. (2008). "Communities as a necessity in information literacy development: Challenging the standards". The Journal of Academic Librarianship.34 (3).

Hatano, G., \& Inagaki, K. (1991). Sharing through collective cognition.

Horakova, L; Bonnet, J; and Congdon, M. Jr. (2017) "Centering Vol.2 Information Literacy (as) Skills and Civic Engagement in the Basic Communication Course: An Integrated Course Library Collaboration," Basic Communication Course Annual. Vol. 29 downloaded from:http://ecommons.udayton.edu/bcca/vol29/iss1/12,

Hicks, A., \& Lloyd, A. (2016). "It takes a community to build a framework: Information literacy within intercultural settings". Journal of Information Science, 42 (3), 334-343Vol 2 (2), (online), (http://scholarworks.sjsu.edu).

Huvila, I. (2011). "The complete information literacy? Unforgetting creation and

Kay, R. H, and Ahmadpour, K. (2015). Negotiating "the Digital Maze of Information Literacy". Journal of Educational Informatics. Diunduh of http://www.journalofeducationalinformatics.ca,

Kuhlthau, CC. (2013). "Rethinking the 2000 ACRL standards".Communications in Information Literacy.7 (2).

Lloyd, A., Kennan, MA, Thompson, KM, \& Qayyum, A. (2013). Connecting with new information landscapes: Information literacy practices of refugees. Journal of Documentation, 69 (1), 121144

Mackey, TR, \& Jacobson, TE Reframing Information Literacy as Metaliteracy.College \& Research Libraries, 72 (1).

Mason, H. \& McCall, S. (Eds.). (1999). Visual Impairment: Access to Education for Children and Young People. London: David Fulton published. 
McMillan, David W. and David M. (1986). "Sense of Community".Journal of Community Physiology. Vol.14. College of Vanderbilt University downloaded fromhttps://pdfs.semanticscholar.org

Murray Shepherd, "Library collaboration: what makes it work? (Keynote paper)." Proceedings of the IATUL Conferences.Paper 47. http://docs.lib.purdue.edu/iatul/2004/papers/47

Nonaka, Ikujiro \& Konno, N. (2000). "SECI BA and Leadership". downloaded fromhttps://www.ai.wu.ac.at/ kaiser/literatur/nonaka-sec-ba-leadership.pdf

Organization of information ".Journal of Librarianship and Information Science. 43 (4), 237245.

. Perspectives on socially shared cognition. Washington, DC: Psychological Association

Pertuni. (2009). "Pertuni VII General Assembly Resolution 2009" downloaded from http://pertuni.idpeurope.org/Resolusi2009/

Riger, S., \& Lavrakas, PJ. (1981). Community ties: Patterns of attachment and social interaction in urban. RK, \& Gordon, MT

Roschelle, J. (1996). Learning by collaborating: Convergent conceptual

Shepherd, M. "Library collaboration: What makes it work" downloaded fromhttp://web.nccu.edu

Stahl, G. (2004). "Building Collaborative Knowing: elements of social theory". downloaded fromhttp://link.springer.com/chapter/10.1007\%2F1-4020-7921-43,

Tuominen, K; Savolainen, R; \& Talja, S. (2005). "Information Literacy as a sociotechnical Practice1".The Library, 75 (3), 329-345.

Yin, R. K. (2003). Case Study Research Design: design and methods. New Delhi: Sage Publications. 